\title{
A NEW SPECIES OF TUPISTRA (CONVALLARIACEAE) FROM SUMATRA
}

\author{
NORIYUKI TANAKA \\ Department of Education, School of Liberal Arts, Teikyo University, \\ 359 Otsuka, Hachioji-shi, Tokyo 192-0395, Japan
}

\begin{abstract}
SUMMARY
Tupistra sumatrensis N. Tanaka, a new species from northern Sumatra, is described and illustrated. Diagnostic notes of this species in comparison with some related species are also provided.
\end{abstract}

Key words: Tupistra grandis, T. grandistigma, T. sumatrensis, T. violacea, Sumatra.

\section{INTRODUCTION}

The genus Tupistra Ker Gawl. (s.str.) is a relatively small genus, comprising about 13 species, and distributed mainly in South and Southeast Asia, including Nepal, Bhutan, India, Myanmar, China, Laos, Vietnam, Thailand and Malaysia.

In the course of revising the genus, a new, very distinct species was found in the material from northern Sumatra, Indonesia. This species is described, illustrated and diagnostically compared with some related ones.

Tupistra sumatrensis N. Tanaka, spec.nov. - Fig. 1,2

A speciebus ceteris Tupistrae (s.str.) haec species nova antheris prope basin tubi perianthii locatis, perianthiis valde longis $(25-30 \mathrm{~mm})$ et ad medium (6-)fissurantis, et pistillis longis (20-25 mm) distinguitur. Etiam ejus spicae longissimae (ad $35 \mathrm{~cm}$ longae) et stigmata irregulariter ramulosissima notabiles sunt. - Typus: Lörzing 13712 (holo BO-1446324), N Sumatra, Karohochebene, near Kabandjahe, 1200-1225 m alt., 21 Aug. 1928, fl.

Tupistra grandis auct. non Ridl.: Jessop (1979) 223, p.p. (f. 14a. T. grandis; f. 14b, c. T. sumatrensis).

Robust entirely glabrous herb. Rhizome and roots not seen. Leaves narrowly obovate, acuminate at apex, long-attenuate and decurrent at base, entire, papery (in sicco), to 112 by $12.5 \mathrm{~cm}$, midvein prominently elevated abaxially, lateral parallel veins many, fine, slightly elevated on both surfaces; petiole poorly defined. Peduncle erect, terete, to $21 \mathrm{~cm}$ long or longer. Spike with many ascending flowers, straight, cylindric, to 35 by c. $4 \mathrm{~cm}$. Bracts 2 per flower; inner one smaller, borne lateral to flower, narrowly ovate to ovate, to $5.5 \mathrm{~mm}$ long, apex slightly curved to apex of spike, slightly cucullate, midrib somewhat ridged dorsally; outer one borne below flower, deltoid, subacute to obtuse at apex, cucullate, to 7 by $4.2 \mathrm{~mm}$. Perianth narrowly campanulate, 6-cleft, somewhat bilabiate, fleshy, dark violet (Lörzing 13712); lobes oblong, obtuse at apex, 12-15 by $5.5-7.5 \mathrm{~mm}$, lowermost 2 recurved more strongly than uppermost 2; tube $12-15 \mathrm{~mm}$ 


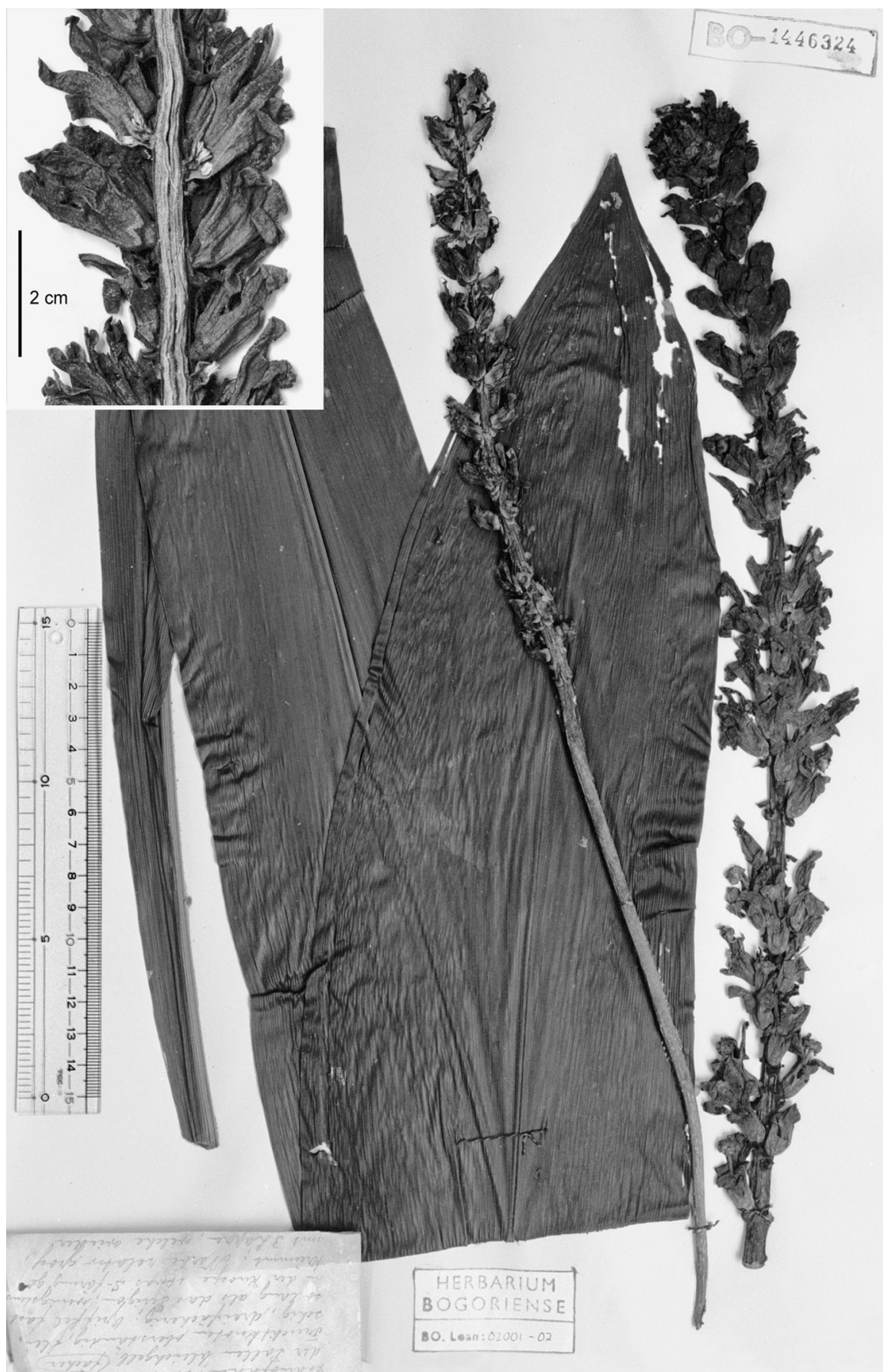

Fig. 1. Tupistra sumatrensis N. Tanaka. Holotype (Lörzing 13712, BO), and part of paratype (Galoengi 91, BO) (in inset) showing part of its inflorescence longitudinally cut. - Scale bar in inset $=2 \mathrm{~cm}$. 


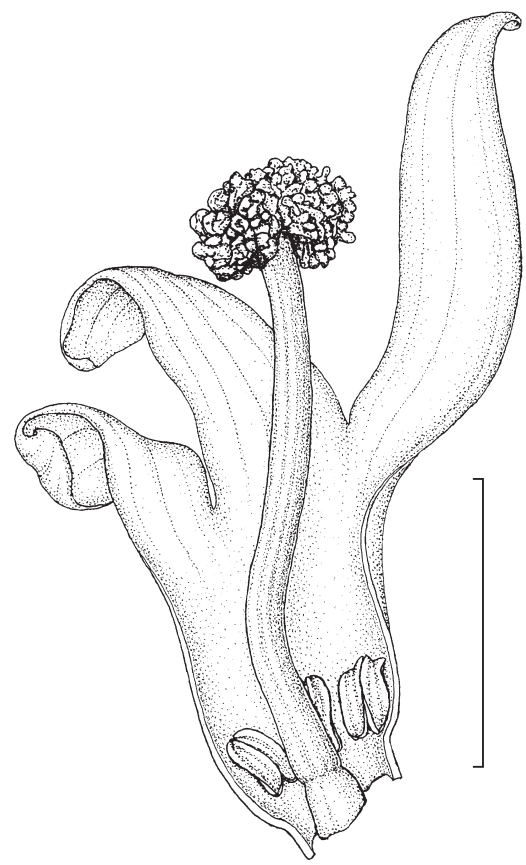

Fig. 2. Tupistra sumatrensis N. Tanaka. Flower longitudinally cut with half of the perianth and three anthers attached to it removed (Galoengi $91, \mathrm{BO})$. - Scale bar $=1 \mathrm{~cm}$.

long, 6-8 mm wide in middle, slightly contracted (3-5 $\mathrm{mm}$ in diameter) or stipiform at base, without pedicel. Stamens 6; anthers elliptic, introrse, 2.5-3 $\mathrm{mm}$ long, creamy in colour (in sicco), sessile, attached dorsally to subbasal portion of perianth tube. Pistil 1; style narrowly cylindric, externally indistinct from ovary, 17-22 $\mathrm{mm}$ long including ovary; stigma exserted from tube, capitate or hemispheric, slightly depressed in centre, irregularly much ramulose, $4.5-7 \mathrm{~mm}$ in diameter, $2.5-4 \mathrm{~mm}$ thick, dark violet (Lörzing 13712); ovary superior, situated at extreme base of columnar pistil, small, 1.5-2 mm high, 3-locular (Lörzing 13712). Berries ovoid to globose, 1.2-2.1 cm across; pericarp thick, carnose, muricate, often with remnant of basal part of style at apex.

Distribution - Indonesia, Northern Sumatra.

Habitat - In forest from c. 600 to 1250 m altitude (Lörzing 13712, 6284; Galoengi 91).

Vernacular name - Singkut (h)antu; Karo-batak (Lörzing 13712; Galoengi 91).

Notes - In general appearance, this new species resembles Tupistra grandis Ridl. described from the Malay Peninsula (Ridley, 1900), but differs clearly from it by the dark violet, capitate, irregularly ramulose stigma (Fig. 2), and by the other diagnostic characters stated above (Fig. 1, 2). In contrast to T. sumatrensis, T. grandis has white, orbicular, thin, spreading stigmas with crenulate margins, anthers located in the middle of the perianth tube, shorter perianths (to $14 \mathrm{~mm}$ long) with lobes shorter than the tube, shorter pistils (to $14 \mathrm{~mm}$ long) and shorter spikes (to $24.5 \mathrm{~cm}$ long).

The genus Tupistra in the Malesian region was reviewed by Jessop (1979). He recognised two species, $T$. violace Ridl. and $T$. grandis, from there. It is apparent that T. sumatrensis is included in his circumscription of $T$. grandis, judging from his account. For instance, figures $14 \mathrm{~b}$ and $14 \mathrm{c}$ of his article (Jessop, 1979) depict the flowers of T. sumatrensis, while figure 14a illustrates the habit of T. grandis. 
The holotype and two other specimens (Galoengi 91 and Lörzing 6284, listed below) of $T$. sumatrensis were formerly annotated on the label as $T$. violacea by Lörzing (Lörzing 6284 is also given the same annotation by Van Steenis). But T. violacea (Ridley, 1904) differs from T. sumatrensis mainly by its anthers located in the middle of the perianth tube, shortly club-shaped or turbinate, unramulose stigmas, shorter perianths (to c. $16 \mathrm{~mm}$ long), shorter pistils (to $11 \mathrm{~mm}$ long) and shorter reclinate spikes (to 13 cm long).

Tupistra sumatrensis also resembles T. grandistigma F.T. Wang \& S. Yun Liang recorded from China (Liang, 1978; Liang \& Tamura, 2000) and Vietnam (Liang \& Tamura, 2000), particularly in its capitate stigmas (Fig. 2), long perianth lobes (Fig. 2) and comparatively large anthers (Fig. 2). Tupistra grandistigma is, however, distinguishable from $T$. sumatrensis chiefly by its anthers located at the base of the perianth lobes, shorter pistils (to $13 \mathrm{~mm}$ long) and shorter perianths (to $22 \mathrm{~mm} \mathrm{long}$ ).

Tupistra sumatrensis is unique in having its anthers near the base of the perianth tube, while its stigma is far exserted from the tube (Fig. 2). No other species of Tupistra has a stigma and anthers within a flower so spatially apart from each other as in T. sumatrensis.

Tupistra sumatrensis is one of the most southerly distributed species in the genus. No specimens of other species of the same genus from Sumatra have been seen by the present author.

Additional specimens examined:

INDONESIA. N Sumatra: Galoengi 91 (BO-1446323), Karohoogvlakte, near Perbesi (west of Kabandjahe), \pm 600 m, 22 Feb. 1919, fl.; Lörzing 6284 (BO-1446325), Karohoogvlakte, near Lingga, \pm 1225 m, 21 Jan. 1919, fr.

\section{ACKNOWLEDGEMENTS}

I am most grateful to the directors and curators of BM, BO, K, P and SING for the loan of the specimens used in this study. I also thank Dr. F. Adema for comments on the manuscript and for information about the specimens of Tupistra sumatrensis housed in L.

\section{REFERENCES}

Jessop, J.P. 1979. Tupistra grandis. In: C.G.G.J. van Steenis (ed.), Flora Malesiana I, vol. 9, part 1: 221-223. Sijthoff \& Noordhoff, Alphen aan den Rijn.

Liang, S.Y. 1978. Tupistra grandistigma. In: F.T. Wang \& T. Tang (eds.), Flora Reip. Pop. Sin. 15: $8-10$, pl. 3. Science Press, Beijing.

Liang, S.Y. \& M.N. Tamura. 2000. Tupistra grandistigma. In: Z.I. Wu \& P.H. Raven (eds.), Flora of China 24: 240. Science Press, Beijing \& Missouri Botanical Garden Press, St. Louis.

Ridley, H.N. 1900. Tupistra grandis. J. Bot. 38: 73.

Ridley, H.N. 1904. Tupistra violacea. J. Straits Branch Roy. Asiat. Soc. 41: 35.

NB: After submission of the manuscript to this journal, I was informed by Dr. F. Adema, managing editor, that duplicates of all the specimens cited above and in addition Lörzing 8743 (N Sumatra, Karohoogvlakte, near Kabandjahe, \pm 1150 m, 21 May 1922) are present in L. All these specimens, according to him, can be identified as Tupistra sumatrensis. That is, one isotype (Lörzing 13712), two isoparatypes (Galoengi 91, Lörzing 6284 ) and another specimen (Lörzing 8743) of the species are kept in L. 